University of Montana

ScholarWorks at University of Montana

$10-2001$

\title{
Grief and Burial in the American Southwest: The Role of Evolutionary Theory in the Interpretation of Mortuary Remains
}

Douglas H. Macdonald

University of Montana - Missoula, douglas.macdonald@umontana.edu

Follow this and additional works at: https://scholarworks.umt.edu/anthro_pubs

Part of the Anthropology Commons

Let us know how access to this document benefits you.

\section{Recommended Citation}

Macdonald, Douglas H., "Grief and Burial in the American Southwest: The Role of Evolutionary Theory in the Interpretation of Mortuary Remains" (2001). Anthropology Faculty Publications. 7.

https://scholarworks.umt.edu/anthro_pubs/7

This Article is brought to you for free and open access by the Anthropology at ScholarWorks at University of Montana. It has been accepted for inclusion in Anthropology Faculty Publications by an authorized administrator of ScholarWorks at University of Montana. For more information, please contact scholarworks@mso.umt.edu. 


\section{Society for American Archaeology}

Grief and Burial in the American Southwest: The Role of Evolutionary Theory in the Interpretation of Mortuary Remains

Author(s): Douglas H. MacDonald

Source: American Antiquity, Vol. 66, No. 4 (Oct., 2001), pp. 704-714

Published by: Society for American Archaeology

Stable URL: http://www.jstor.org/stable/2694183

Accessed: 30/10/2013 13:16

Your use of the JSTOR archive indicates your acceptance of the Terms \& Conditions of Use, available at http://www.jstor.org/page/info/about/policies/terms.jsp

JSTOR is a not-for-profit service that helps scholars, researchers, and students discover, use, and build upon a wide range of content in a trusted digital archive. We use information technology and tools to increase productivity and facilitate new forms of scholarship. For more information about JSTOR, please contact support@jstor.org. 


\title{
GRIEF AND BURIAL IN THE AMERICAN SOUTHWEST: THE ROLE OF EVOLUTIONARY THEORY IN THE INTERPRETATION OF MORTUARY REMAINS
}

\author{
Douglas H. MacDonald
}

\begin{abstract}
Evolutionary theory, in consort with Marxism and processualism, provides new insights into the interpretation of grave-good variation. Processual interpretations of burial sites in the American Southwest cite age, sex, or social rank as the main determinants of burial-good variation. Marxist theorists suggest that mortuary ritual mediates social tension between an egalitarian mindset and an existing social inequality. Evolutionary theory provides a supplementary explanatory framework. Recent studies guided by kin-selection theory suggest that humans grieve more for individuals of high reproductive value and genetic relatedness. Ethnographic examples also show that individuals mourn more intensively and, thus, place more social emphasis on burials of individuals of highest reproductive value (young adults). Analysis of grave goods from La Ciudad, a Hohokam site in the American Southwest, supports the hypothesis that labor value, reproductive value, and grief contributed to gravegood differentiation. At La Ciudad, individuals between the ages of 10 and 20 possessed more and higher-quality grave goods on average than any other age group. Grief at the loss of a young adult of high reproductive and labor value may facilitate explanation of mortuary variation at La Ciudad, as well as other sites in the greater Southwest and beyond.
\end{abstract}

La teoría de evolución, en conjunto con el Marxismo y el procesualismo, proporciona nuevas luces en la interpretación de la variabilidad las ofrendas funerarias. Las interpretaciones procesuales de sitios de entierros en el suroeste de los Estados Unidos citan edad, sexo o la categoría social como determinantes principales de la variabilidad de las ofrendas funerarias. Los teóricos marxistas sugieren que el rito mortuorio equipara la tensión social entre un estado mental igualitario y una desigualdad social existente. La teoría de evolución proporciona un marco complementario, con el cual se puede examinar el problema. Estudios recientes guiados por la teoría de la selección de parentesco sugieren que los humanos se afligen más por los individuos con alta capacidad para reproducirse y con los cuales están geneticamente relacionados. Ejemplos de etnografía muestran también que la gente lamenta más intensamente y pone más énfasis social en los funerales de las personas de mayor capacidad para reproducirse (adultos jóvenes). El análisis de funerales de La Ciudad, un sitio de los Hohokam en el suroeste de los Estados Unidos, apoya la hipótesis de que el valor laboral, la capacidad reproductiva y el duelo contribuyeron a las distinciones funerarias. En La Ciudad, los individuos entre las edades de 10 y 20 años tuvieron mayor calidad de tumbas en promedio que los de cualquier otra edad. El duelo por la pérdida de un adulto joven de alto valor reproductivo y laboral puede explicar la variación mortuaria en La Ciudad, así como en otros sitios del gran suroeste de los Estados Unidos y de más allá.

$\mathrm{M}$ arxist and processual theories have contributed to a more complete understanding of prehistoric society. McGuire's (1992a) Marxist interpretations of burials at the Hohokam site of La Ciudad, for example, set a precedent for identification of masked social inequality. I will suggest in this paper, however, that the Marxist approach is incomplete in its explanation of high grave lot values in sub-adult burials at La Ciudad. In still other cases, processualists fail to account for differences in burial wealth, as at the Salado site of Togetzoge (Hohman and Kelly 1988). Evolutionary theory provides a supplementary framework in which to interpret mortuary remains at these two sites.

As Ian Morris (1992:1) states, "a funeral is part of a set of rituals by which the living deal with death." But not all deaths are treated equally, as grief, ceremony, burial type, and grave goods vary according to a variety of social, biological, and economic factors. In this paper, using kin-selection theory, grief studies, and ethnographic analogy (see Morris 1987:211), I suggest that grave-good variation at La Ciudad marks not only the valuable labor potential of young adults, as proposed by McGuire, or social

Douglas H. MacDonald ^ GAI Consultants, Inc., 570 Beatty Road, Monroeville, PA, 15146- 1300

American Antiquity, 66(4), 2001, pp. 704-714

Copyright@ 2001 by the Society for American Archaeology 
ranking, as proposed by processualists (Binford 1971; Hohman and Kelly 1988; Saxe 1970), but also the mourner's level of grief, an adaptive biological response. Recent grief studies suggest that levels of grief vary based on the deceased's reproductive value-the higher the reproductive value, the higher the grief. Thus, young adults, who possess the highest reproductive value, are grieved for more than others. In turn, more elaborate ceremonies are held and more grave goods are placed in their burials. The implications of this process for the archaeological record are clear, as some archaeological sites are likely to contain extremely rich young-adult burials. As will be seen, evolutionary theory, processualism, and Marxism are not mutually exclusive and, when used in tandem, can provide powerful and parsimonious explanations of archaeological problems.

\section{Method and Theory in Mortuary Studies}

Processual archaeologists (e.g., Binford 1971, 1972; O'Shea 1984; Saxe 1970; Tainter 1978; Trinkaus 1995; see Brown 1995 for an overview of the SaxeBinford mortuary analysis method) generally interpret intrasite mortuary variation as a direct reflection of social rank (Carr 1995:106, 109, 112; Morris 1992:21-23). A typical interpretation, such as that provided by Binford (1971, 1972:232), states that "the social scale of the deceased should vary directly with the relative rank of the social position held by the deceased." Or, as Trinkaus (1995:54) states, "Mortuary patterning is ... evidence ... for the level of internal differentiation in prestate societies."

Post-processualists (Hodder 1982; Shanks and Tilley 1982; see VanPool and VanPool 1999 for a review) and Marxists (McGuire 1992b) critique this straightforward reading of mortuary remains. Do mortuary remains always reflect the status of the deceased, or are there other, more complex social operations at play, such as the masking of inequality (Trinkaus 1995:57)? To resolve such questions, archaeologists have focused their attention upon other important issues, such as prehistoric gender relations (Claassen and Joyce 1997; Crown and Fish 1996; Gero and Conkey 1991) and social inequality (Duke 1991; Duke and Wilson 1995).

One aim of the Marxist approach to mortuary studies is to understand "the implicit assumptions in a society that both perpetuate (reproduce) and mask unequal power relations" (McGuire 1992a:13). Marxist archaeologists strive to explain the contra- dictions, for example, between an egalitarian ideology and a society fraught with inequality (Preucel and Hodder 1996:301). In this approach, then, the mortuary record is seen to be in contradiction to, not a reflection of, the living social sphere.

\section{Kin-Selection Theory and Grief Intensity}

While processual, post-processual, and Marxist archaeologies have been important theoretical forces in Americanist archaeology, in the last 20 years evolutionary theories have become increasingly popular among American archaeologists (see Broughton and O'Connell 1999 for a brief review). Kin-selection theory, in particular, provides a complementary explanatory framework to the processual and Marxist views briefly outlined above. Using evolutionary theory, I elaborate upon McGuire's (1992a) suggestion that a loss of labor value provoked the high abundance of grave goods in burials of young adults at the Hohokam site of La Ciudad. While labor value was likely a contributing factor to grave-good variation, the expectation for such a model is that adults would have the most and highest-quality grave goods. In contrast, in a kin-selection model, one would expect that young adults, given their heightened reproductive value, would be grieved for more than others and would receive preferential treatment during burial. As discussed below, ethnographic examples from small-scale foraging and farming societies, as well as archaeological data, support a kin-selection-based explanation for grave-good variation at $\mathrm{La}$ Ciudad.

\section{Kin Selection and Grief}

Recent studies use kin-selection theory to explain differential levels of human grief. Such studies also facilitate a better understanding of human biological response to death in prehistoric contexts. W. D. Hamilton (1964) first used kin-selection theory to explain altruistic behavior between individuals. In Hamilton's view, adaptations may be propagated in two ways: 1) by natural selection increasing the probability that an organism will have offspring (Darwin 1964 [1859]); and 2) by kin selection, through increasing the probability that an organism's kin will produce offspring. The central concept of Hamilton's rule is inclusive fitness, as accounted for in the formula $C<r B$. Altruism ought to be extended to kin when the cost of assisting $(C)$ is less than the product of the individual's benefit $(B)$ discounted by the 
coefficient of relatedness between actor and recipient, $r$. Calculation of inclusive fitness includes not only one's own fecundity (ability to reproduce), but also the fecundity of one's kin.

Alexander (1979) describes another key attribute of kin selection, which he calls Hamilton's second rule: when genetic relatedness of potential recipients is equal, relatives with greatest ability to translate benefits into reproduction will be favored. This is an important concept, as it suggests that individuals will devote more aid to kin with greater reproductive value. By reproductive value, I mean "the extent to which persons of a given age and sex will contribute, on average, to the ancestry of future generations" (Buss 1997:176; Fisher 1958). For example, in order to maximize inclusive fitness, an individual is predicted to devote fewer resources in the aid of a postreproductive individual than of someone in their reproductive prime.

Despite critiques (e.g., Sahlins 1977), Hamilton's rules have since been corroborated by studies among nonhuman primates (Harcourt and De Waal 1992; Hrdy 1976) and humans (Blurton Jones and Sibly 1978; Daly and Wilson 1988; Hawkes 1983; Hawkes et al. 1997; Hill and Hurtado 1991). It has also been shown that in certain circumstances reciprocal altruism (Trivers 1971) between non-kin also facilitates individual fitness (Ashton et al. 1998; Patton 2000). For example, in many small-scale societies, while most food and other resources are shared primarily within a nuclear family, it is also beneficial to expand sharing networks beyond close kin to minimize the risks of long-term subsistence failure (Gould 1982; Kelly 1995:176). Reciprocal altruism, thus, solves Sahlins's (1977) major critique of kinselection theory, that human social groups are composed of both kin and non-kin and that aid is allocated to all individuals.

If one accepts kin selection and the concept of inclusive fitness, it also stands to reason that not only will aid be differentially allocated by degree of relatedness and potential fecundity, but levels of grief should also vary according to Hamilton's rules. Evolutionary psychological studies (Crawford et al. 1989; Littlefield and Rushton 1986; Segal and Bouchard 1993) have shown that grief does in fact vary according to the predictions: individuals mourn most deeply for relatives of highest genetic relatedness and reproductive value. The findings of these cross-cultural studies suggest that grief and other "emotions are important biological responses ... and are perhaps evolutionarily adaptive" (Segal and Bouchard 1993:87), a notion first suggested by Darwin (1872).

For example, Crawford et al. (1989) evaluated the hypothesis that grief levels correspond to reproductive value of individuals. In their cross-cultural study, which included individuals from British Columbia, Japan, South Africa, as well as Howell's (1979) data on !Kung Bushmen (Figure 1), reproductive values peaked for males and females between the ages of 15 and 20 (Crawford et al. 1989:302; see also Buss 1997:176). They also found that there was a very strong and significant relationship $(r=.75, p<.05)$ between levels of parental grief and the reproductive value of deceased children.

Life-history data on the Ache foragers of Paraguay (Hill and Hurtado 1996:415) suggest variation in the duration of the peak reproductive value (Figure 1). For the Ache, female reproductive value peaked between the ages of 15 and 20, but that of males peaked between ages 15 and 25 . While grief and burial have not been studied among the Ache, we should expect that intensive grieving corresponds to these respective age groups and that deaths of a broader segment of the male population (ages 15-25) than the female population (ages 15-20) would experience increased grief.

The results of these evolutionary psychological studies suggest that grief is a function of Hamilton's rules. Relative degree of relatedness will affect levels of grief, but, more importantly for this paper, those individuals with highest potential fecundity will be grieved for more than others. As Crawford et al. (1989:305) state, "the finding that the intensity of grief is . . highly correlated with reproductive values . . suggests that a certain amount of "hardwiring' may influence our reactions to the death of children of different ages."

\section{Ethnographic Studies, Reproductive Value, and Grave-Good Variation}

These evolutionary psychological studies confirm the cross-cultural link between grief and reproductive value. Young adults with high reproductive value are grieved for more intensively than individuals of other age groups. An important question for this study is whether ethnographic studies also show a corresponding link between heightened grief and increased grave goods and mortuary ceremony for young adults. 


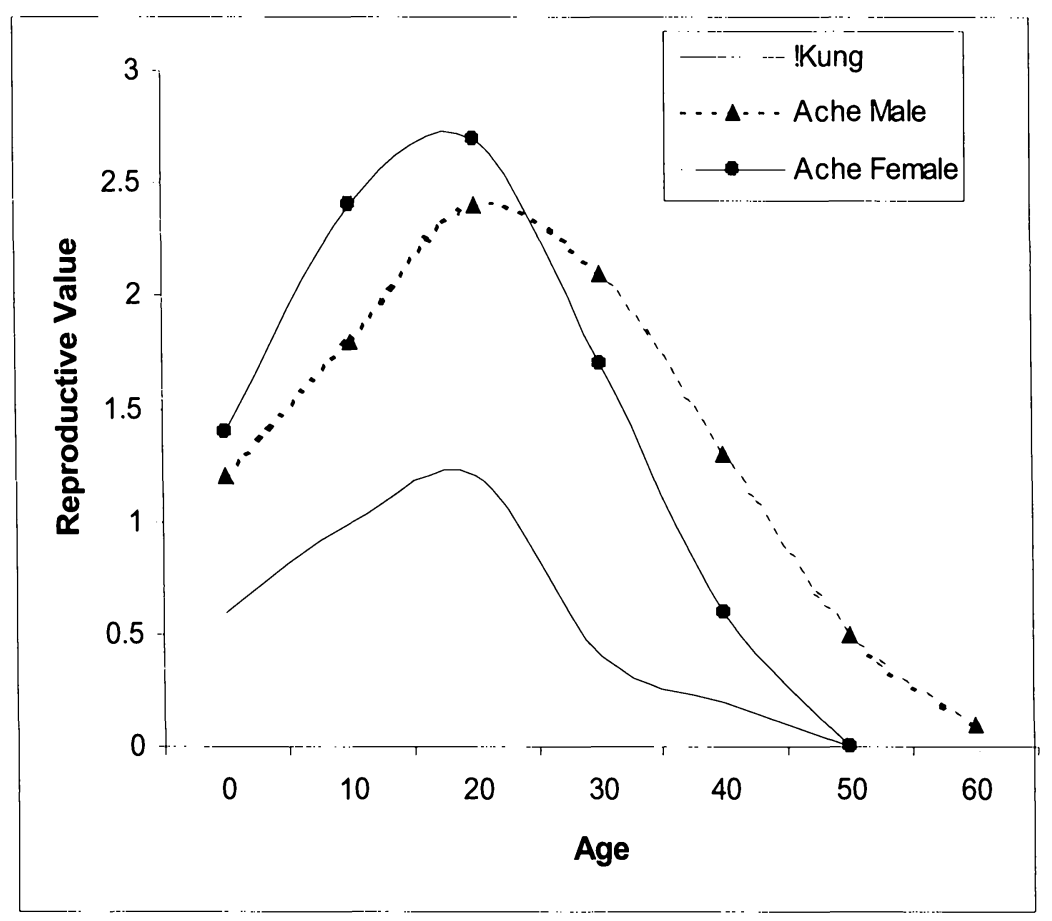

Figure 1. Reproductive value of !Kung and Ache women and Ache men (after Crawford et al. 1989:302; Hill and Hurtado 1996:415; Howell 1979).

While data on treatment of young adult burials is scant, anecdotal ethnographic evidence supports the hypothesis that young adult burials are provided increased elaboration. In Goody's (1962) overview of the Lodagaa agropastoralist burial practices in West Africa, young adult burials received more attention and ceremonial elaboration than those of infants or the elderly, and fathers always mourn more deeply for sons, than do sons for fathers. As Goody (1962:92) explains it, "the death of a member of the junior generation stands in contradiction to the normal progression of human life. Consequently, a young person's funeral, except that of an infant, is a more bitter experience than the obsequies of either a parent or a grandparent."

Bendann's (1930) research also shows that some Australian Aborigines treat infants and elderly individuals significantly differently than young adults. For example, children who died prior to the age of four were thought to not have souls and their bodies were interred without ceremony. Similarly, the elderly were buried immediately upon death and were not treated to a burial ritual, as occurred for young adults. Bendann (1930:205) adds that "when a young man dies in Frazier Island [Queensland,
Australia], the survivors first skin him, then cut off his flesh, and finally extract the marrow from his bones. . . . But when the old and 'stale' die, their bodies are placed on the boughs of trees" without ceremony.

Ethnographic research into differential mortuary treatment of young adults is scarce; however, these anecdotal cases suggest that in some small-scale cultures, young adults are differentially cared for upon death. They are given more elaborate ceremony and grief is more intense than for infants and elderly. These cases suggest that grief varies according to age at death and that, for young adults, this grief translates into increased mortuary ceremony.

\section{Expectations Regarding Grave-Good Variation at Archaeological Sites}

Given the correspondence between reproductive value and grave-good variation among some contemporary peoples, it stands to reason that, at some archaeological sites, we should observe increased grave-good quantities and values in young adult burials. Such relationships should be most obvious in small-scale societies that lack social stratification. Ascribed and achieved status hierarchies will 
be overlaid on, and may partly mask, these anticipated patterns. When status is ascribed at birth based on ancestry it may vary little over the course of a lifetime. Thus, wealthy burials should crosscut age groups, with high ascribed-status infants, young adults, and adults all having increased gravegood quantities and values, such as occurs at some Hopewell sites in midwestern North America (Braun 1982).

In achieved-status hierarchies, older adults are most likely to have heightened grave-good values (Binford 1972:226). In such cultures, while a few extremely capable young adults might achieve status, most young adults have not lived long enough to earn increased status. In these hierarchies, cultural norms may overwhelm the adaptive grief response and it will be considered culturally unacceptable to translate grief into grave-good abundance. Durham (1991:223) would call such cultural rules "secondary value selection," in which decision making is governed by cultural values, often established by an elite governing body. While grief may be more intense for the deaths of young adults in such societies, there should be no correspondence with grave-good values.

I suggest that foragers and small-scale horticulturalists that lack ascribed-status hierarchies and in which achieved statuses are relatively nonprivileged are the most likely to exhibit grave-good variation based on reproductive value and grief. Archaeological data from the site of La Ciudad in Arizona (Figure 2) are used below to suggest that the Colonial-Sedentary Hohokam culture was largely egalitarian with most grave-good variation being explained by kin-selection theory.

\section{Hohokam Culture History and Social Organization}

Beginning as early as 1000 to 500 B.C., farmers settled into sedentary pithouse communities in the southern deserts of Arizona (Figure 2) (Bayman et al. 1997; Crown and Fish 1996; Crown and Judge 1991; Shaul and Hill 1998). Focused mainly in the Phoenix (also known as the core or Salt-Gila) and Tucson basins, these farmers established a regional system of trade, pottery production, minor irrigation canals and ballcourts between roughly A.D. 150 and 775 (the Pioneer period of the Hohokam culture; Gumerman 1991). Agricultural production in the core area was dependent upon the perennial Salt and

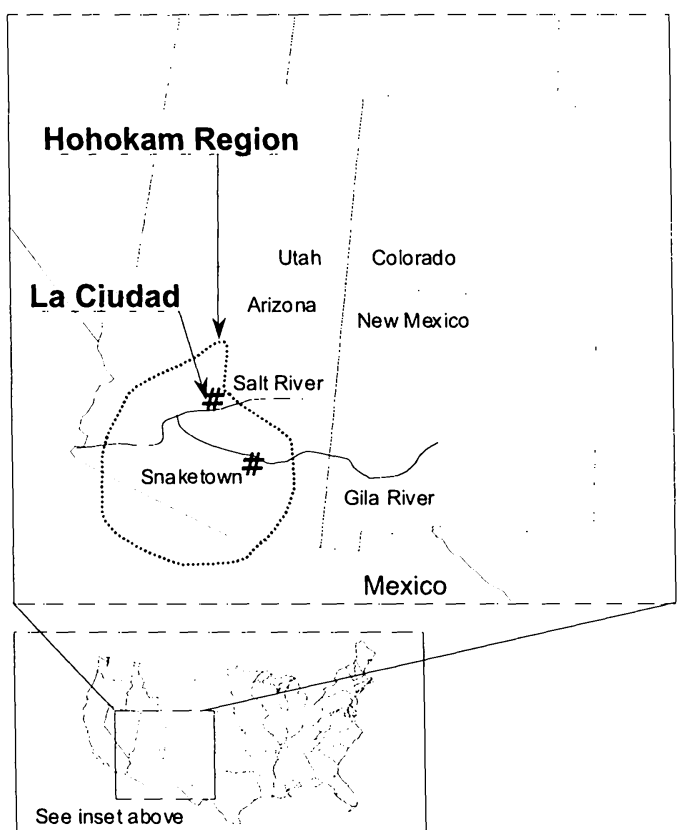

Figure 2. Location of sites discussed in text.

Gila Rivers, which pass through the region (McGuire 1992a:4) (Figure 2). Between A.D. 850 and 1000 (the Colonial Period), Hohokam ballcourt construction intensified and villages were focused along the SaltGila Rivers and connecting canals. Between A.D. 1000 and 1100 , in the Sedentary period, the Hohokam phenomenon reached its widest extent (Haury 1976). In the subsequent Classic period, the Hohokam reorganized into a clearly different and highly socially stratified society (McGuire 1992a:6).

As Upham et al. (1994:194) state, "the Salt-Gila Basin and surrounding areas never operated in concert politically or economically" with the regional ballcourt system during the Colonial and Sedentary periods. Certain sites, based on site hierarchy and location, participated in the system more than others. Prior to A.D. 1150, archaeological research reveals that some Hohokam communities, such as Snaketown-with its irrigation canals, calichecapped mounds, and ballcourts (Haury 1976; Wilcox 1991:49-50)—already were taking steps toward Classic period levels of social stratification (Crown and Fish 1996; Doyel 1984:154; Doyel 1991). Crown and Fish (1996:807-812) have also shown that gender hierarchies were present to some degree during the Colonial and Sedentary periods.

Nevertheless, other sites, such as La Ciudad (the focus of this paper) lack clear evidence of social 


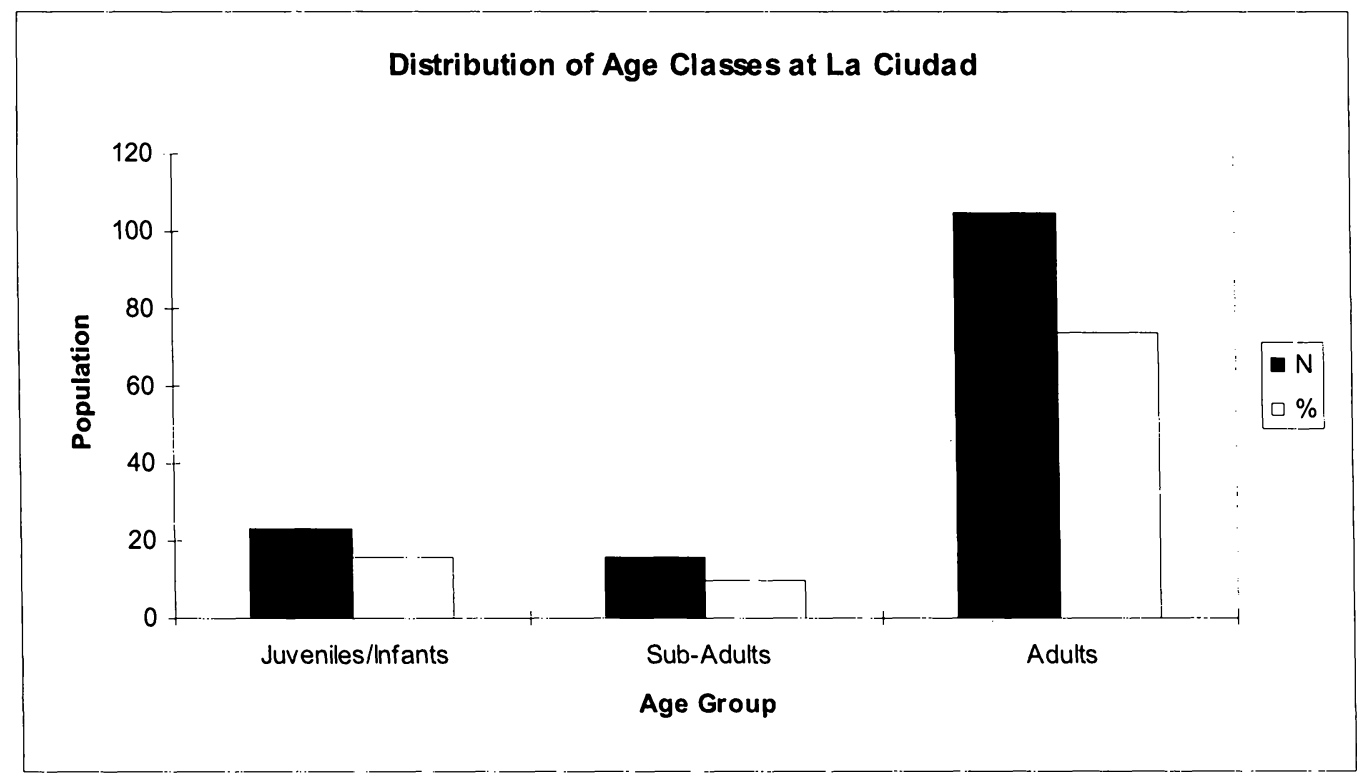

Figure 3. Age distribution of skeletons from La Ciudad: Juvenile/Infants (ages $<10)$; sub-adults (10-20); and adults (>20) (after McGuire 1992a:133).

inequality (McGuire 1992a). As a result, some researchers argue that Colonial-Sedentary Hohokam society was largely egalitarian (Seymour 1988), with an uncentralized economy that was still heavily reliant on the use of reciprocal kin relationships (Crown 1990:238). The lack of architectural features indicative of status hierarchy is one clear distinction between the Colonial-Sedentary and the Classic Hohokam (Crown and Fish 1996:806). As McGuire (1992a:6) states, "Despite the expansion of public architecture, domestic structures continue to be relatively ephemeral shallow pithouses little changed from the [Pioneer period]." Thus, debate continues regarding the nature of Colonial-Sedentary Hohokam society.

\section{Kin Selection, Grief, and Burial Interpretation at La Ciudad}

\section{La Ciudad}

In his book Death, Society and Ideology (1992a), McGuire uses a Marxist framework to examine Hohokam society. At La Ciudad, a major ColonialSedentary period site in the lower Salt River basin of Arizona (see Figure 2), McGuire (1992a) analyzed mortuary remains from over 200 burials dating between A.D. 725 and 1100. Figure 3 summarizes the age distribution of the Hohokam population in
McGuire's study (McGuire 1992a:133). Of 143 identifiable burials (McGuire excludes Sedentary Period cremations), 105, or 74 percent, were adults, 23 (16 percent) were infants/juveniles (age $<10$ ) and only 16 (10 percent) were sub-adults (between the ages of 10 and 20).

Comparative probability-of-death data for preindustrial populations (Hill and Hurtado 1996:210-211; Howell 1979:96) suggest comparatively greater infant mortality rates than observed in the La Ciudad population. Based on these comparative ethnographic data, infants are likely under-represented in McGuire's La Ciudad sample by as much as 10 percent, possibly due to preservation bias. This bias must be taken into consideration when attempting to understand social inequality via comparison of the quantities and values of grave goods in burials of variously aged individuals. It should be further noted that the burials in this sample from $\mathrm{La}$ Ciudad are cremations. Cremated individuals are much more difficult to age and sex. As McGuire (1992a:84) states, "the under-representation of infants and children and the possibility that a significant portion of unaged remains in a population may be younger individuals need to be considered in evaluations of social status and wealth distributions based on grave lots." 


\section{Hohokam Social Inequality?}

In contrast to some Colonial-Sedentary sites such as Snaketown (Wilcox 1991:50-51), architectural features at La Ciudad suggest little social inequality. As interpreted by McGuire (1992a:157), "The mundane, day-to-day world of the Colonial and Sedentary period Hohokam [as seen in architecture] reinforced an ideology that ... denied inequality in the social order." However, he goes on to state that differential expression of social inequality in mortuary goods vs. visible architectural features is precisely the type of contradiction anticipated in a Marxist perspective.

If architecture served to reinforce the ideology of disguised inequality, McGuire suggests that "in the mortuary display at La Ciudad, the inequalities within courtyard groups were expressed, possibly even exaggerated." As McGuire states (McGuire 1992a:157), "On average, the richest burials were those of courtyard heads who appeared to have achieved their status in their lifetime," suggesting that the Hohokam who lived at La Ciudad maintained an achieved-status hierarchy in which individuals accrued status over time and with experience (Binford 1972:226; O'Shea 1984). While architecture promoted an egalitarian mindset, grave-good differences signaled the presence of some underlying social inequalities in Hohokam life.

\section{Kin Selection, Grief, and the La Ciudad Burials}

Such considerations, however, do not explain all the grave-good variation at La Ciudad. As Figure 4 shows, and as McGuire states in his next sentence, "The richest burials ... included sub-adults too young to have achieved much status; sub-adults, on average, had richer grave lots than juveniles or adults." In terms of quantities of grave goods, sub-adults had the highest mean (9.33 items/person) compared to 3.41 for adults and 1.96 for juveniles (Figure 4).

McGuire also assigned a mean grave-lot value (GLV) to each burial. GLV is a composite value for all grave goods in a burial. McGuire's ranking system was not based solely upon the quantities of items in the grave; he gave more value to artifacts manufactured from nonlocal or exotic materials and to those showing increased effort in manufacture. Items were also assigned value, based on their inferred social context, in the following order: ritual-burial, ornamental, or ordinary. An item produced from an exotic material (e.g., turquoise), requiring a high labor input (e.g., a finely shaped pendant), and produced for a ritual-burial context had the highest relative value.

At La Ciudad, mean grave-lot value (as estimated by McGuire 1992a:128) for individual burials was highest (11.25) for sub-adults (ages 10-20), with adults next (9.04), followed by juveniles (6.43) and infants (.50) (Figure 4). These GLV data only partially support McGuire's assertion that masked social inequality existed at La Ciudad. The fact that the second-highest values of grave goods in both cases (quantity and value) was for adults suggests some form of accrued status inequality. However, burials of individuals between the ages of 10 and 20 consistently held more and higher-quality pots, necklaces, jars, and rare stones.

McGuire clearly identifies this fact and suggests that labor value was the driving force behind wealth in sub-adult burials. $\mathrm{He}$ (1992a:152) states that "the age-category with the highest GLV and the most diverse collection of artifacts were those of subadults age 10-20 years. . . Sub-adults were 15 times more likely to be buried with shell beads than adults and five times more likely to be buried with shell bracelets. This age-category was clearly marked as special status in the La Ciudad cemeteries." He states in explanation of this fact that, "in particular, they were well endowed with ornaments, perhaps reflecting the efforts of courtyard groups to woo them or keep them within the courtyard labor pool."

Labor for the construction of large networks of irrigation ditches and canals as well as for field maintenance (Doyel 1984:153-154, Doyel 1991:8) was vital to Colonial-Sedentary Hohokam farming success. However, if labor status resulted in differential burial wealth, then adults, with power positions in the labor force, should be given preferential treatment in burials (as among Classic period Hohokam burials; Crown and Fish 1996). Some adults, as noted above, do indeed possess large amounts of highquality grave goods. Thus, McGuire's hypothesis is partially substantiated. Indeed, the fact that young adults possessed high grave-lot values likely reflects in part the kin group's lost labor value. However, evolutionary theory suggests that other factors, especially their reproductive value and lost inclusive fitness, contributed to the relative importance of young-adult burials. 


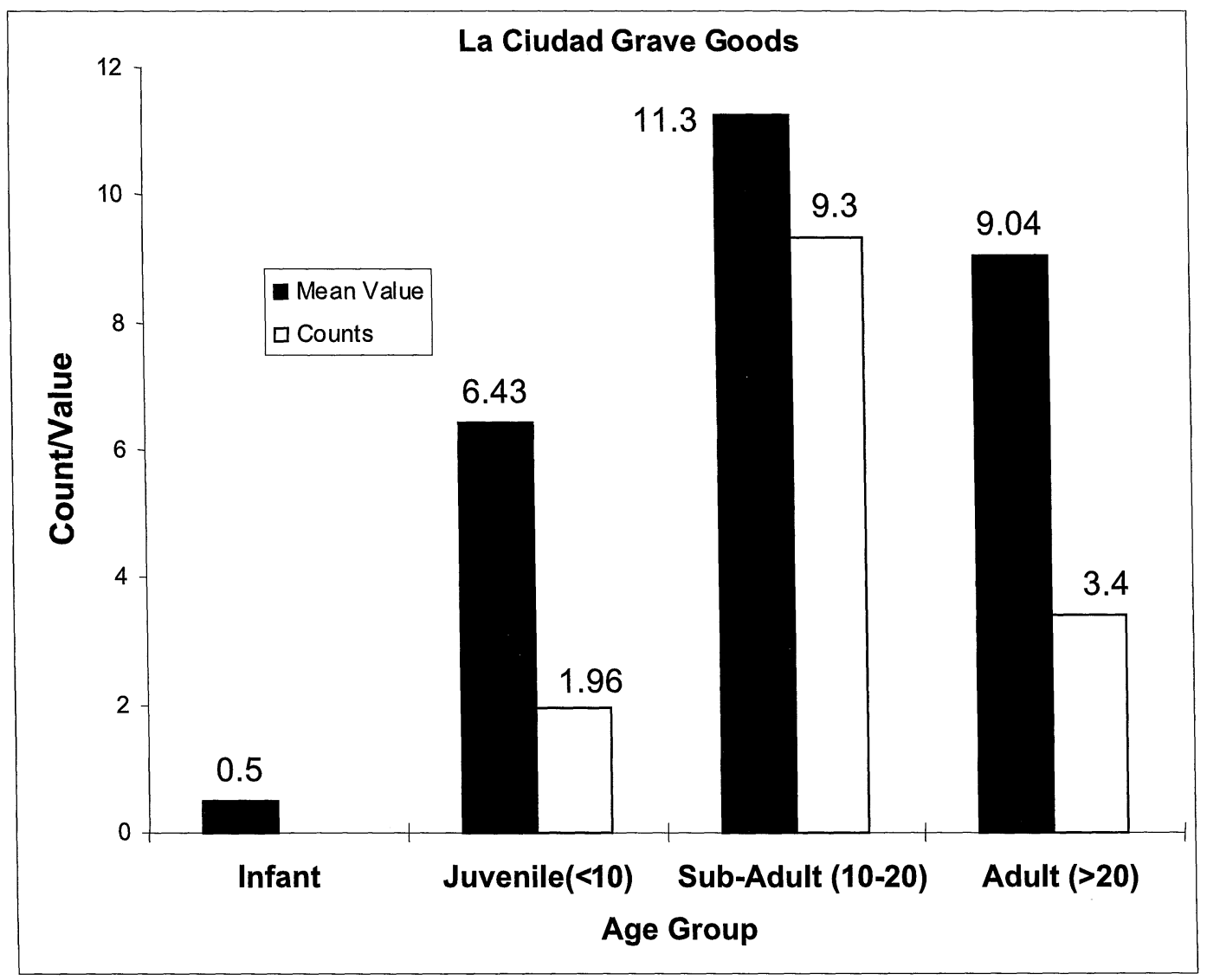

Figure 4. Grave-good quantities and values at the Hohokam site of La Ciudad (data from McGuire 1992a:110, 133).

\section{Evolutionary Theory and the La Ciudad Burials}

As noted above, individuals grieve more deeply for those with the most reproductive value, young adults to whom they are closely related. As described above, ethnographic case-studies suggest that in nonstratified societies (e.g., hunter-gatherers and some horticulturalists; Carr 1995), we might expect to observe a correlation between amount of grave goods and reproductive value of the deceased individual. Young adults may be deferentially cared for in burial contexts because of both the rarity of deaths of individuals of these ages and their increased reproductive value (Figure 1) in relation to other members of society.

The loss of a young adult is an unfortunate blow to members of any society, but especially to one based predominantly in kin groups, such as McGuire suggests for the Colonial-Sedentary Hohokam at La Ciudad. Using an analogy to the Yumans, McGuire (1992a:151) suggests that the success of the new kin-group house depended on the "fecundity of the founding couple and their ability to attract new members. . . . Some founding couples are more fertile, effective, and persuasive than others and attract a larger group of kin, followers and dependents."

Rather than solely a loss of labor, thus, the loss at La Ciudad was also in reproductive value. The grief of the parents and of other members of the kin group is directly proportionate to their degree of relation and to the level of reproductive value. The death of a sub-adult was a major loss to both the labor pool as well as to the inclusive fitness of kin. One wasn't only losing a son or daughter, one was losing many potential grandchildren and greatgrandchildren. The grief felt by each kin relation and each friend, thus, is a normal biological response to the loss of inclusive fitness. In the end, those subadults are mourned more heavily than others, more elaborate rituals take place, and more grave goods are placed in their burials. 


\section{Discussion and Alternative Explanations}

La Ciudad represents only one case and it is unclear if kin-selection theory can explain grave-good placement at other Colonial-Sedentary Hohokam sites. Indeed, as we have seen, there are plausible supplementary explanations for the grave-good patterning at La Ciudad. As a biological reaction to death, grief supplements the cultural explanations of masked social inequality and labor value proposed by McGuire. McGuire's adept analysis suggests that the social inequality revealed in mortuary ceremony contradicted and undermined the egalitarian ideology in the community.

In addition, the Saxe-Binford processual model is useful as well, as it is clear that the La Ciudad burials reflect in part "rules . . . dictated by the larger [achieved status] social system" (Saxe 1970:4). While some adults likely possessed wealthy graves due to accrued status, the data (see Figure 4) reveal that young adult graves contained more and better grave goods than any other group. The evolutionary psychological and ethnographic examples, as well as the explanatory power of kin-selection theory, provide a convincing argument that heightened grief related to reproductive value of young adults was an important part of grave-good variation at La Ciudad.

Additional explanations of increased grave goods in young-adult burials need to be considered briefly. A complementary evolutionary explanation is that young adults are more likely to wear jewelry as adornment to attract mates, which may translate into higher grave-good counts and values. It is also is plausible that young adults lacked descendants who could inherit their belongings, and, thus, their belongings were buried with them. For example, personal ornaments, such as necklaces, likely belonged to the deceased and bowls may have held food for the afterlife. A final alternative explanation is that the death of young adults created a power vacuum in a group that may have been exploited by competing kin groups. Thus, the burial ceremony was intended to show other competing groups that despite the death, the mourning group was still strong and wealthy.

Another problem exists in the supposition that increased grief translates into increased grave goods. While this paper has drawn such a connection, only a handful of ethnographic accounts discuss this interrelationship. More ethnographic study of grave-good placement as it relates to age and status is necessary to refine this link between grave goods and degree of grief.

These alternative explanations are important to consider, because this paper is not intended to end the debate, but to begin it. The discussion of the mortuary remains at La Ciudad is intended to illustrate the value of evolutionary theory as an explanatory framework complementary to Marxist and processual interpretation. Used in tandem, these approaches provide a more complete explanation of Hohokam mortuary remains at La Ciudad. Further research needs to evaluate whether the pattern revealed at $\mathrm{La}$ Ciudad is present at other Colonial-Sedentary Hohokam sites and at additional sites in the American Southwest and beyond.

\section{Conclusion}

As Schiffer (1999:167) recently stated, "Given the wide range of current questions, we must acknowledge that theories from diverse programs are needed to help answer them." It is misleading to presume that a single theoretical perspective will solve the numerous problems of the archaeological record. As this paper has shown, evolutionary theory complements processualism (Hohman and Kelley 1988; Mitchell 1994) and Marxism (McGuire 1992a). Each explains a portion of the variance in this example and together they provide more complete answers than any one can accomplish alone.

This paper is also a cautionary warning against the notion that grave-good variation reflects only social inequality. A complementary interpretation of variation in mortuary remains at some sites is that sub-adult deaths were particularly tragic. Grief related to loss of inclusive fitness and labor value, in this model, translates into increased quality and quantity of grave goods. As Preucel and Hodder (1996:311) suggest, "It is not enough simply to describe burial practices and relate them socially to power. . ." Indeed, this study suggests that differential power and social inequality are vital to an explanation of mortuary remains. However, inequality is best considered one of several considerations, among them grief, that factor into a complete understanding of mortuary remains (Carr 1995) and burial ritual (Morris 1992). Ultimately, evolutionary theory complements Marxist and processual interpretations of mortuary remains in that, in a coevolutionary sense (Durham 1991), biology (e.g., the adaptive response of grief) joins culture (e.g., social 
inequality and labor) in a more comprehensive explanation.

Acknowledgments. Thank you to the following individuals for sharing opinions, comments and editorial advice on prior drafts of this paper: Timothy Kohler, Randall McGuire, Lynne Goldstein, Patricia L. Crown, Douglas R. Mitchell, Barry Hewlett, Gary Huckleberry, William Lipe, Karen Lupo, Diane Curewitz, and three anonymous referees. Thanks to the Department of Anthropology at Washington State University and GAI Consultants, Inc. for providing resources that facilitated the completion of this paper. My gratitude also to Claudia Bazán-Arias of GAI Consultants, Inc. who translated the abstract into spanish.

\section{References Cited}

Alexander, R. D.

1979 Darwinism and Human Affairs. University of Washington Press, Seattle.

Ashton, M. C., S.V. Paunonen, E. Helmes, and D. N. Jackson

1998 Kin Altruism, Reciprocal Altruism, and the Big Five Personality Factors. Evolution and Human Behavior 19:243-256.

Bayman, J. M., M. R. Palacios-Fest, and L.W. Huckell

1997 Botanical Signatures of Water Storage Duration in a Hohokam Reservoir. American Antiquity 62:103-111.

Bendann, E.

1930 Death Customs: An Analytical Study of Burial Rites. A.E. Knopf, New York.

Binford, L. R.

1971 Mortuary Practices: Their Study and Their Potential. In Approaches to the Social Dimensions of Mortuary Practices, edited by J. Brown, pp. 6-29. Society for American Archaeology Memoir 25, Washington, D.C.

1972 Mortuary Practices: Their Study and Their Potential. In An Archaeological Perspective, edited by L. R. Binford, pp. 208-251. Seminar Press, New York.

Blurton Jones, N., and R. M. Sibly

1978 Testing Adaptiveness of Culturally Determined Behavior: Do Bushmen Women Maximize Their Reproductive Success By Spacing Births Widely and Foraging Seldom? In Human Behavior and Adaptation, edited by N. Blurton Jones and V. Reynolds, pp. 135-157. Taylor and Francis LTD, London.

Braun, D. P.

1982 The Snyders Mounds and Five Other Mound Groups in Calhoun County, Illinois. Museum of Anthropology Technical Reports No. 13. University of Michigan, Ann Arbor.

Broughton, J. M., and J. F. O'Connell

1999 On Evolutionary Ecology, Selectionist Archaeology, and Behavioral Archaeology. American Antiquity 64:153-165.

Brown, J.

1995 On Mortuary Analysis, with Special Reference to the Saxe-Binford Research Program. In Regional Approaches to Mortuary Analysis, edited by L.A. Beck, pp. 3-28. Plenum Press, New York.

Buss, D. M.

1997 Sex Differences in Human Mate Preferences: Evolutionary Hypotheses tested in 37 Cultures. In Human Nature, edited by L. Betzig, pp. 175-190. Oxford University Press, New York. Originally Published 1989, Behavioral and Brain Sciences 12(1-14)

Carr, C.
1995 Mortuary Practices: Their Social, Philosophical-Religious, Circumstantial, and Physical Determinants. Journal of Archaeological Method and Theory 2:105-200.

Claassen, C., and R. A. Joyce (editors)

1997 Women in Prehistory: North America and Mesoamerica. University of Pennsylvania Press, Philadelphia.

Crawford, C. B., B. E. Salter, and K. L. Jang

1989 Human Grief: Is Its Intensity Related to the Reproductive Value of the Deceased? Ethology and Sociobiology 10:297-307.

Crown, P. L.

1990 The Hohokam and the American Southwest. Journal of World Prehistory 4:223-255.

Crown, P. L., and S. K. Fish

1996 Gender and Status in the Hohokam Pre-Classic to Classic Transition. American Anthropologist 98:803-817.

Crown, P. L., and W. J. Judge (editors)

1991 Chaco and Hohokam:Prehistoric Regional Systems in the American Southwest. School of American Research Press, Santa Fe.

Daly, M., and M. Wilson 1988 Homicide. Aldine de Gruyter, New York.

Darwin, C.

1872 The Expression of the Emotions in Man and Animals. Murray Press, London.

1964 [1859] On the Origin of Species, A Facsimile of the First Edition. Harvard University Press, Cambridge, Massachusetts.

Doyel, D. E.

1984 From Foraging to Farming: An Overview of the Preclassic in the Tucson Basin. The Kiva 49:147-165.

1991 The Hohokam: Ancient Dwellers of the Arizona Desert. In The Hohokam: Ancient People of the Desert, edited by D. G. Noble, pp. 3-16. School of American Research Press, Santa Fe.

Duke, $P$.

1991 Points in Time. University Press of Colorado, Niwot.

Duke, P., and M. C. Wilson (editors)

1995 Beyond Subsistence: Plains Archaeology and the Postprocessual Critique. The University of Alabama Press, Tuscaloosa.

Durham, W. H.

1991 Coevolution: Genes, Culture, and Human Diversity. Stanford University Press, Stanford, California.

Fisher, R. A.

1958 The Genetical Theory of Natural Selection. Dover Press, New York.

Gero, J. M., and M. W. Conkey (editors)

1991 Engendering Archaeology: Women and Prehistory. Blackwell Publishers, Cambridge.

Goody, J.

1962 Death, Property, and the Ancestors: A Study of the Mortuary Customs of the Lodagaa of West Africa. Stanford University Press, Palo Alto.

Gould, R. A.

1982 To Have and Have Not: The Ecology of Sharing among Hunter-Gatherers. In Resource Managers: North American and Australian Hunter-Gatherers, edited by N. M. Williams and E. S. Hunn, pp. 69-92. AAAS Selected Symposium 67. Westview Press, Boulder.

Gumerman, G. J. (editor)

1991 Exploring the Hohokam: Prehistoric Desert Dwellers of the Southwest. University of New Mexico Press, Albuquerque.

Hamilton, W. D.

1964 The Genetical Evolution of Social Behavior, I and II. Journal of Theoretical Biology 7:1-52. 
Harcourt, A. H., and F. B. M. de Waal (editors)

1992 Coalitions and Alliances in Humans and Other Animals. Oxford University Press, New York.

Haury, E.

1976 The Hohokam: Desert Farmers and Craftsmen. University of Arizona Press, Tucson.

Hawkes, K.

1983 Kin Selection and Culture. American Ethnologist 10:345-363.

Hawkes, K., J. F. O'Connell, and N. G. Blurton Jones

1997 Hadza Women's Time Allocation, Offspring Provisioning, and the Evolution of Long Postmenopausal Life Spans. Current Anthropology 38:517-550.

Hill, K., and M. Hurtado

1991 The Evolution of Reproductive Senescence and Menopause in Human Females. Human Nature 2:315-340. 1996 Ache Life History: The Ecology and Demography of a Foraging People. Aldine de Gruyter, New York.

Hodder, I

1982 Symbols in Action: Ethnoarchaeological Studies of Material Culture. Cambridge University Press, New York.

Hohmann, J. W., and L. B. Kelley

1988 Eric F. Schmidt's Investigations of Salado Sites in Central Arizona. Museum of Northern Arizona Bulletin 56. Museum of Northern Arizona Press, Flagstaff.

Howell, N.

1979 Demography of the Dobe!Kung. Academic Press, New York.

Hrdy, S. B.

1976 The Care and Exploitation of Nonhuman Primate Infants by Conspecifics other than the Mother. Advances in the Study of Behavior 6:101-158.

Kelly, R. L.

1995 The Foraging Spectrum. Smithsonian Institution Press, Washington, D.C.

Littlefield, C. H., and J. P. Rushton

1986 When a Child Dies: The Sociobiology of Bereavement. Journal of Personality and Social Psychology 51:797-802.

McGuire, R. H.

1992a Death, Society, and Ideology in a Hohokam Community. Westview Press, Boulder.

1992b A Marxist Archaeology. Academic Press, New York.

Mitchell, D. R.

1994 The Pueblo Grande Project, Volume 7: An Analysis of Classic Period Mortuary Patterns. Soil Systems Publications in Archaeology 20(7):1-282.

Morris, I.

1987 Burial and Ancient Society: the Rise of the Greek CityState. Cambridge University Press, New York.

1992 Death-Ritual and Social Structure in Classical Antiquity. Cambridge University Press, New York.

O'Shea, J. M.

1984 Mortuary Variability: An Archaeological Investigation. Academic Press, New York.

Patton, J. Q.

2000 Reciprocal Altruism and Warfare: A Case Study from the Ecuadorian Amazon. In Human Behavior and Adaptation, edited by N. Chagnon, L. Cronk, and W. Irons, pp. 417436. Aldine de Gruyter, New York.
Preucel, R. W., and I. Hodder (editors)

1996 Contemporary Archaeology in Theory. Blackwell Publishers, Cambridge.

Sahlins, M.

1977 The Use and Abuse of Biology. University of Michigan Press, Ann Arbor.

Saul, M. B.

1988 Mortuary Practices. In The 1982-1984 Excavations at Las Colinas, Material Culture. Arizona State Museum Archaeological Series 162:413-461.

Saxe, A. A.

1970 Social Dimensions of Mortuary Practices. Doctoral dissertation, University of Michigan, Ann Arbor. University Microfilms International, Ann Arbor.

Schiffer, M. B.

1999 Behavioral Archaeology: Some Clarifications. American Antiquity 64:166-168.

Segal, N. L., and T. J. Bouchard, Jr.

1993 Grief Intensity Following the Loss of a Twin and Other. Relatives: Test of Kinship Genetic Hypotheses. Human Biology 65:87-105.

Seymour, D. J.

1988 An Alternate View of Sedentary Period Hohokam ShellOrnament Production. American Antiquity 53:812-828.

Shanks, M., and C. Tilley

1982 Ideology, Symbolic Power and Ritual Communication: A Reinterpretation of Neolithic Mortuary Practices. In Symbolic and Structural Archaeology, edited by I. Hodder, pp. 129-154. Cambridge University Press, New York.

Shaul, D. L., and J. H. Hill

1998 Tepimans, Yumans and Other Hohokam. American Antiquity 63:375-396.

Tainter, J. A.

1978 Mortuary Practice and the Study of Prehistoric Social Systems. Advances in Archaeological Method and Theory 1:106-143.

Trinkaus, E.

1995 Mortuary Behavior, Labor Organization, and Social Rank. In Regional Approaches to Mortuary Analysis, edited by L.A. Beck, pp. 101-124. Plenum Press, New York.

Trivers, R. L.

1971 The Evolution of Reciprocal Altruism. Quarterly Review of Biology 46:35-57.

Upham, S., P. L. Crown, and S. Plog

1994 Alliance Formation and Cultural Identity in the American Southwest. In Themes in Southwest Prehistory, edited by G. J. Gumerman, pp. 183-210. School of American Research Press, Santa Fe.

VanPool, C. S., and T. L. VanPool

1999 The Scientific Nature of Postprocessualism. American Antiquity 64:33-54.

Wilcox, D. R.

1991 Hohokam Religion: An Archaeologist's Perspective. In The Hohokam: Ancient People of the Desert, edited by D.G. Noble, pp. 47-61. School of American Research Press, Santa $\mathrm{Fe}$.

Received October 29, 1998; Revised November 13, 2000;

Accepted March 21, 2001. 